Artikel Penelitian

\title{
Evaluasi Tingkat Kebisingan Kawasan Selatan Universitas Negeri Padang
}

\author{
Vera Surtia Bachtiar, Reri Afrianita dan Ary Zamzamy \\ Jurusan Teknik Lingkungan, Universitas Andalas, Kampus Unand Limau Manis Padang, 25163, Indonesia
}

\section{ARTICLE INFORMATION}

Received: 15 November 2017

Revised: 15 December 2017

Available Online: 31 Januari 2018

\begin{tabular}{l} 
KEYWORDS \\
\hline Noise level \\
Universitas Negeri Padang \\
Sound level meter \\
Noise level standard \\
Noise control \\
CORRESPONDENCE \\
\hline Phone:- \\
E-mail: verasurtia@eng.unand.ac.id \\
\hline
\end{tabular}

\section{PENDAHULUAN}

Universitas Negeri Padang (UNP) merupakan kawasan kampus yang memiliki aktivitas sangat beragam mulai dari kegiatan belajar mengajar, ekstra kurikuler, perkantoran, perdagangan, transportasi dan kegiatan pembangunan. UNP merupakan perguruan tinggi hasil konversi IKIP Padang yang diputuskan oleh surat Keputusan Presiden Republik Indonesia Nomor 093 Tahun 1999.

UNP memiliki tujuh fakultas dengan 101 program studi (Bagian Umum, Hukum/Tatalaksana dan Perlengkapan Universitas Negeri Padang, 2012). Kawasan UNP sendiri tidak hanya terdapat fasilitas-fasilitas kampus sebagai penunjang kegiatan akademik mahasiwa, tetapi juga terdapat fasilitas penunjang lainnya, seperti Lembaga Penjamin Mutu Pendidikan (LPMP) Sumatera Barat, Taman Kanak-kanak (TK), Sekolah Dasar (SD), Sekolah Menengah Pertama (SMP) dan Sekolah Menengah Atas (SMA) Pembangunan.

Tingginya kegiatan dari para penghuni kampus serta aktivitas sarana transportasi dapat menimbulkan tekanan suara yang tinggi atau kebisingan, sementara kawasan kampus memerlukan lingkungan yang tenang dan sehat.
Tekanan suara yang tinggi berdampak pada aktivitas dan konsentrasi mahasiswa dalam belajar dan secara tidak langsung bila terpapar secara kontinyu dan dalam durasi waktu tertentu dapat menimbulkan gangguan kesehatan (Alfaris, 2008).

Tingkat kebisingan yang ditoleransi untuk kawasan peribadatan dan institusi akademik serta sejenisnya menurut Keputusan Menteri Negara Lingkungan Hidup (KepMenLH) No. 48 Thn 1996 Tentang Baku Tingkat Kebisingan yaitu sebesar 58 dBA (standar $55 \mathrm{dBA}$ ditambah dengan toleransi sebesar $3 \mathrm{dBA}$ ). Hasil penelitian pendahuluan di UNP Kampus Air Tawar menunjukkan tingkat kebisingan sebesar 68,44 dBA dan 72,51 dBA di titik depan Mesjid Al-Azhar UNP serta depan Fakultas Teknik UNP, sedangkan tingkat kebisingan interior yang terjadi sebesar 53,65 dBA yang berada di ruang kuliah bersama Fakultas Teknik. Nilai ini memperlihatkan bahwa tingkat kebisingan di kawasan UNP Kampus Air Tawar melebihi baku tingkat kebisingan. Sehubungan dengan hal tersebut perlu dilakukan penelitian lebih lanjut mengenai sumber, tingkat kebisingan, serta reaksi penghuni kampus mengenai kebisingan di Kampus 
UNP Air tawar Padang dan dibandingkan dengan peraturan yang telah ditetapkan oleh KepMenLH No. 48 Tahun 1996.

Penelitian ini bertujuan untuk untuk menentukan tingkat kebisingan di lingkungan kampus Universitas Negeri Padang baik eksterior maupun interior, membandingkan dengan baku tingkat kebisingan dan alternatif pengendalian yang bisa diterapkan untuk lokasi-lokasi yang melebihi baku tingkat kebisingan.

\section{METODOLOGI}

Penelitian ini terdiri dari survey pendahuluan, pengukran tingkat tekanan suara, penyebaran kuisioner dan alternatif pengendalian kebisingan.

Survei pendahuluan terdiri atas identifikasi kawasan, studi pendahuluan, pengumpulan data sekunder, dan kalibrasi alat. Pengukuran tingkat tekanan suara dilakukan pada tempat dan waktu yang telah ditetapkan. Peralatan yang digunakan dalam pengukuran tingkat kebisingan adalah Sound Level Meter (SLM).

Penentuan waktu sampling berpedoman KepMenLH No. 48 Tahun 1996 tentang Baku Tingkat Kebisingan. Lamanya waktu pengukuran untuk menentukan tingkat kebisingan adalah selama 24 jam $\left(\mathrm{L}_{\mathrm{SM}}\right)$. Dengan asumsi pada siang hari tingkat aktivitas yang paling tinggi selama 16 jam $\left(\mathrm{L}_{\mathrm{S}}\right)$ pada selang waktu 06.00-22.00 WIB dan aktivitas malam hari selama 8 jam $\left(\mathrm{L}_{\mathrm{M}}\right)$ pada selang waktu 22.00-06.00 WIB. Setiap pengukuran harus dapat mewakili selang waktu tertentu dengan menetapkan 4 waktu pengukuran siang hari dan 3 waktu pengukuran malam hari. Pencatatan tingkat tekanan suara dilakukan setiap 5 detik selama 10 menit, waktu-waktu pengukuran tersebut adalah sebagai berikut:

- $\mathrm{L}_{1}$ terletak antara 06.00-09.00 WIB;

- $\mathrm{L}_{2}$ terletak antara 09.00-14.00 WIB;

- $\mathrm{L}_{3}$ terletak antara 14.00-17.00 WIB;

- $\mathrm{L}_{4}$ terletak antara 17.00-22.00 WIB;

- $\mathrm{L}_{5}$ terletak antara 22.00-24.00 WIB;

- $\mathrm{L}_{6}$ terletak antara 24.00-03.00 WIB;

- $\mathrm{L}_{7}$ terletak antara 03.00-06.00 WIB.

Penyebaran kuesioner yang akan dilakukan di kawasan UNP Kampus Air Tawar ditentukan dengan persamaan slovin. Dengan jumlah populasi mahasiswa UNP berjumlah 33.926 pada tahun 2012 (Bagian Umum, Hukum/Tatalaksana dan Perlengkapan Universitas Negeri Padang, 2012) dan standar error data yang diinginkan sebesar $5 \%$ maka didapatkan jumlah kuesioner yang akan disebar sebesar 399,98 kuesioner dengan pembulatan ke atas menjadi 400 kuesioner. Hasil penentuan jumlah sampel kuesioner tersebut merupakan jumlah total untuk seluruh kawasan UNP Kampus Air Tawar, baik bagian utara maupun selatan, sehingga jumlah kuesioner yang akan disebar khusus untuk kawasan selatan UNP Kampus Air Tawar berjumlah 200 lembar kuesioner, yang masing-masing 200 kuesioner untuk area eksterior dan 200 kuesioner untuk area interior. Berikut contoh perhitungan untuk menentukan jumlah sampel kuesioner yang akan disebarkan.

$$
\mathrm{N}=\frac{N}{1+N \cdot \theta^{2}}
$$

Keterangan:

$\mathrm{n}=$ Jumlah sampel kuesioner

$\mathrm{N}=$ Jumlah Populasi

$\theta=$ Standar error yang diinginkan (5\%)

$\mathrm{n}=\frac{34.926}{1+34.926 .(0,05)^{2}}$

$\mathrm{n}=399,98 \approx 400$ lembar kuesioner (total)

$\mathrm{n}_{\text {selatan }}=\frac{(n) \text { total }}{2}=\frac{400}{2}=200$ lembar kuesioner

Pengukuran dilakukan di kawasan UNP baik eksterior maupun interior, dengan perincian seperti Tabel 1.

Tabel 1. Lokasi pengukuran

\begin{tabular}{|c|c|c|c|c|c|}
\hline \multirow[b]{2}{*}{ No. } & \multirow{2}{*}{$\begin{array}{l}\text { Gedung dan } \\
\text { Fasilitas } \\
\text { Penunjang }\end{array}$} & \multirow{2}{*}{$\begin{array}{l}\text { Jumlah } \\
\text { Lantai }\end{array}$} & \multirow{2}{*}{$\begin{array}{c}\text { Lokasi } \\
\text { Ruangan } \\
\text { Kuliah/ } \\
\text { Kelas }\end{array}$} & \multicolumn{2}{|c|}{$\begin{array}{c}\text { Jumlah Lokasi } \\
\text { Pengukuran }\end{array}$} \\
\hline & & & & $\begin{array}{l}\text { Ekste } \\
\text {-rior }\end{array}$ & $\begin{array}{l}\text { Inte- } \\
\text { rior }\end{array}$ \\
\hline 1. & $\begin{array}{l}\text { Fakultas } \\
\text { Teknik (FT) }\end{array}$ & 1 & Lantai 1 & 3 & 1 \\
\hline 2. & $\begin{array}{l}\text { Fakultas } \\
\text { Bahasa, } \\
\text { Sastra dan } \\
\text { Seni (FBSS) }\end{array}$ & 5 & $\begin{array}{l}\text { Lantai } 1, \\
3,4 \text { dan } 5\end{array}$ & 2 & 1 (Lantai 1) \\
\hline 3. & $\begin{array}{l}\text { Fakultas } \\
\text { Ilmu } \\
\text { Keolahraga } \\
\text { an (FIK) }\end{array}$ & 3 & $\begin{array}{c}\text { Lantai } 1 \\
\text { dan } 2\end{array}$ & 2 & 1 (Lantai 1) \\
\hline 3. & $\begin{array}{l}\text { SMA, SMP } \\
\text { dan SD }\end{array}$ & 1 & Lantai 1 & 1 & 3 (Lantai 1) \\
\hline 5. & GOR FIK & 2 & - & 1 & - \\
\hline 6. & $\begin{array}{l}\text { Mesjid Al- } \\
\text { Azhar }\end{array}$ & 3 & - & 1 & 1 \\
\hline 7. & $\begin{array}{l}\text { Balai } \\
\text { Bahasa }\end{array}$ & 1 & - & 1 & - \\
\hline 8. & Poliklinik & 1 & - & 1 & - \\
\hline 9. & $\begin{array}{l}\text { Rektorat } \\
\text { sementara }\end{array}$ & 1 & - & 1 & - \\
\hline 10. & $\begin{array}{ll}\text { Jalan } & \& \\
\text { Parkiran } & \\
\end{array}$ & - & - & 3 & - \\
\hline \multicolumn{4}{|c|}{ Junlah } & 16 & 7 \\
\hline \multicolumn{4}{|c|}{ TOTAL } & & 23 \\
\hline
\end{tabular}

\section{HASIL DAN PEMBAHASAN}

Tingkat energi ekivalen (Leq) merupakan tingkat kebisingan tetap selama periode perhitungan tertentu yang mewakili jumlah energi yang digunakan pada tingkat kebisingan kontinu yang berubah-ubah dalam periode tersebut (Cunniff, 1977). Hasil perhitungan Leq, LS, LM dan LSM menunjukkan angka yang bervariasi. Nilai LS diperoleh dari perhitungan Leq pada rentang waktu L1 s.d L4. Sedangkan nilai LM diperoleh dari perhitungan Leq pada rentang waktu L5 s.d L7 yang kemudian dilanjutkan dengan menghitung LSM yang diperoleh dari LS dan LM. Grafik L1-L7 dapat dilihat pada gambar 1 . 


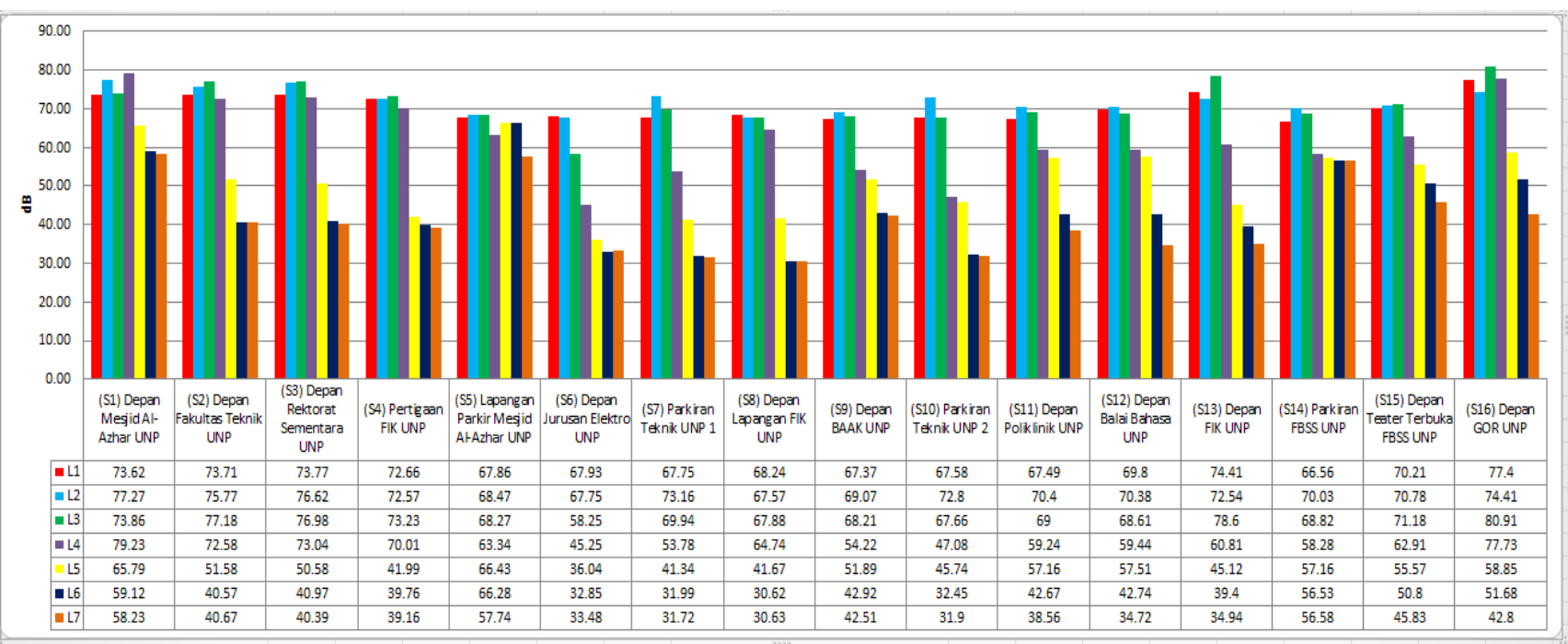

Gambar 1. Grafik $\mathrm{L}_{1}-\mathrm{L}_{7}$ Eksterior di Kawasan Selatan UNP Kampus Air Tawar

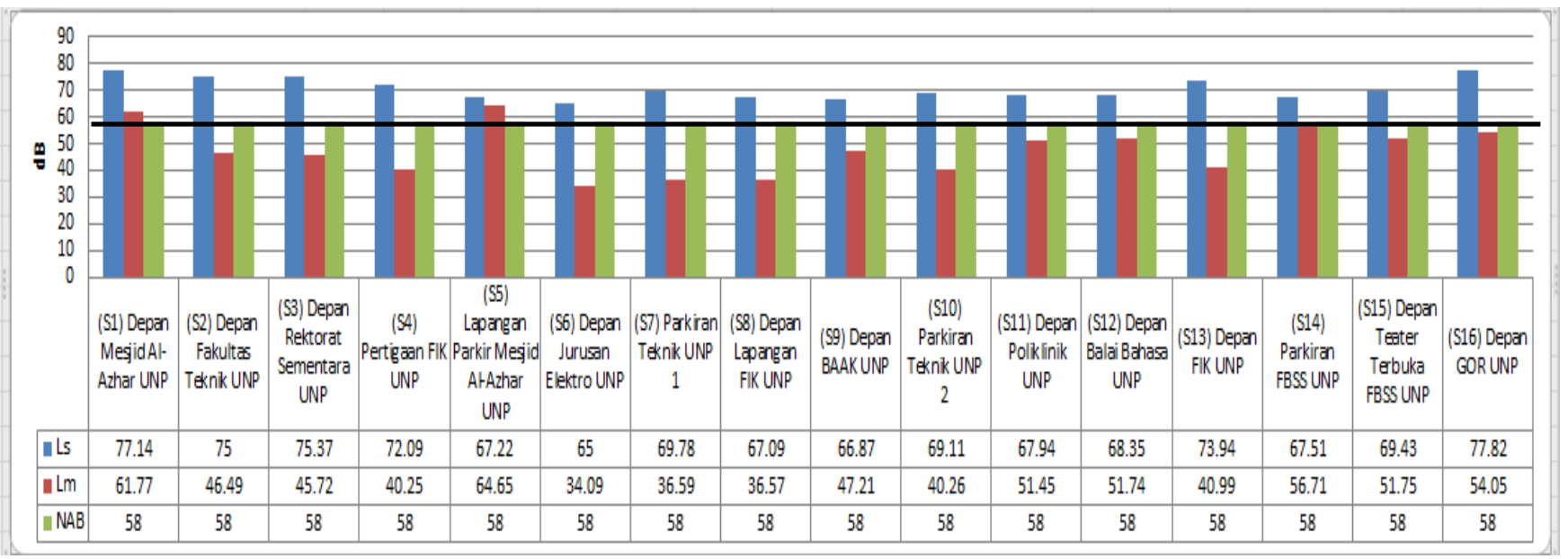

Gambar 2. Grafik Ls, L dengan Baku Tingkat Kebisingan KepMenLH No. 48 Th. 1996

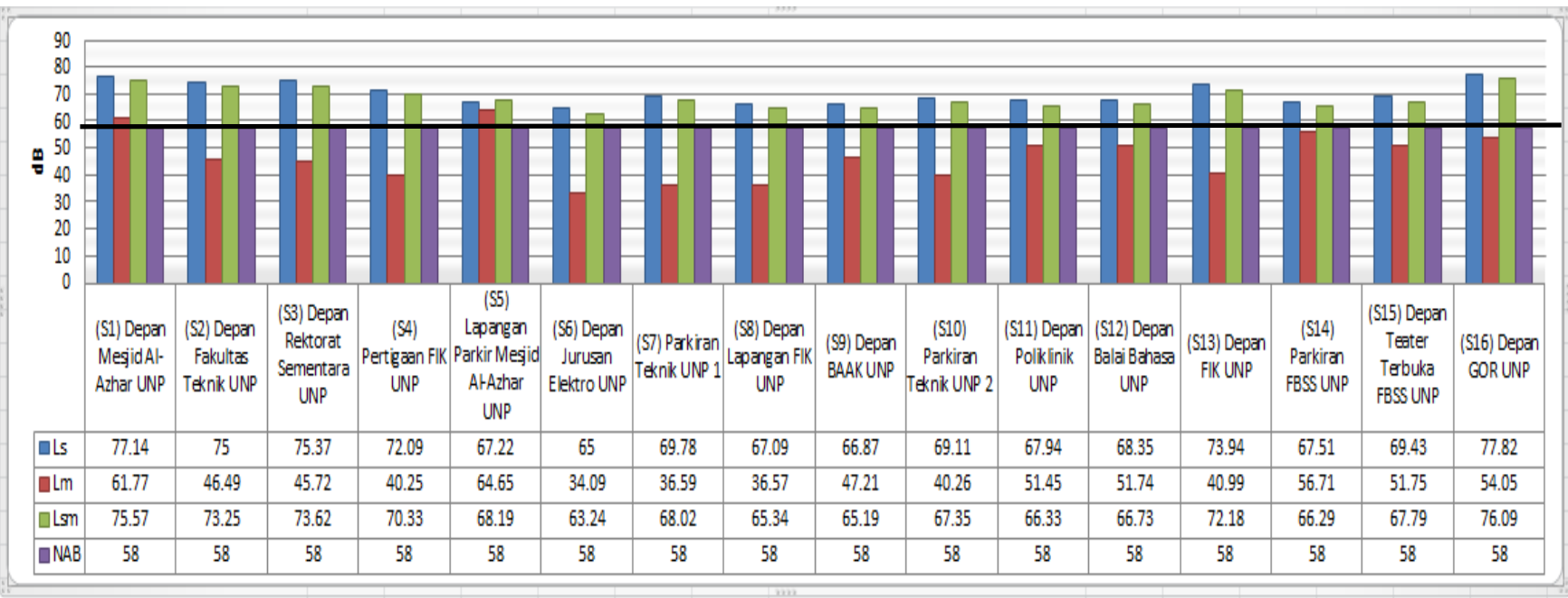

Gambar 3. Grafik Ls, LM, LsM dengan Baku Tingkat Kebisingan KepMenLH No. 48 Th. 1996

Gambar 1 menunjukkan bahwa wilayah dengan tingkat kebisingan tertinggi terjadi pada saat L1 - L3 yaitu pada Titik S1, S2, S3, S4, S13 dan Titik S16 yaitu dengan rentang nilai sekitar 72-80 dBA. Sedangkan untuk L4, tingkat kebisingan https://doi.org/10.25077/dampak.15.1.7-15.2018 tertinggi terjadi pada Titik S1 dengan nilai sekitar 79,23 dBA.

Sedangkan dari Gambar 2, dapat dilihat bahwa tingkat kebisingan tertinggi terjadi pada L5 yaitu pada Titik S1 yaitu 
dengan nilai sekitar 65,79 dBA, sedangkan untuk L6 nilai tingkat tekanan suara tertinggi terjadi di Titik S5 dengan nilai sekitar 66,28 dBA. Untuk L7 nilai tingkat tekanan suara tertinggi terjadi di Titik S1 dengan nilai sekitar 58,23 dBA. Perbandingan nilai LS, LM, LSM dengan baku mutu yang ditetapkan oleh KepMenLH No. 48 Th. 1996 diperlihatkan pada gambar 2 dan 3 .

Grafik perbandingan LS dan LM yang disajikan pada Gambar 2 diatas memperlihatkan bahwa wilayah yang paling berfluktuasi atau dengan selisih LS dan LM tertinggi terdapat pada Titik S3 yaitu sebesar 31,84 dBA. Hal ini disebabkan karena sumber bising pada siang hari terutama berasal dari transportasi sedangkan pada malam hari jumlah kendaraan jauh berkurang. Untuk kebisingan dengan fluktuasi rendah terdapat pada Titik S5 yaitu sebesar 2,57 dBA. Hal tersebut menunjukkan bahwa potensi terjadinya kebisingan akibat aktivitas transportasi pada saat siang hari dan malam hari tidak terlalu jauh berbeda.

Grafik perbandingan LS dan LM yang disajikan pada Gambar 2 di atas memperlihatkan bahwa wilayah yang paling berfluktuasi atau dengan selisih LS dan LM tertinggi terdapat pada Titik S3 yaitu sebesar 31,84 dBA. Hal ini disebabkan karena sumber bising pada siang hari terutama berasal dari transportasi sedangkan pada malam hari jumlah kendaraan jauh berkurang. Untuk kebisingan dengan fluktuasi rendah terdapat pada Titik S5 yaitu sebesar 2,57 dBA. Hal tersebut menunjukkan bahwa potensi terjadinya kebisingan akibat aktivitas transportasi pada saat siang hari dan malam hari tidak terlalu jauh berbeda.

Pada Gambar 3 terlihat perbandingan LS, LM dan LSM dimana Grafik LS bernilai hampir sama dengan Grafik LSM, sedangkan Grafik LM berada jauh dibawah dua grafik lainnya kecuali pada titik S5, sebab titik tersebut berada dekat dengan jalan utama Prof. Dr. Hamka yang durasi aktivitas transportasinya hampir 24 jam setiap hari.

Dari gambar 2 dan 3 maka dapat dilihat seluruh nilai LS dan LSM yang diperoleh melebihi baku mutu tingkat kebisingan yang ditetapkan oleh KepMenLH no. 48 Th. 1996 yaitu 55 $\mathrm{dBA}$, ditambah toleransi $+3 \mathrm{dBA}$ menjadi $58 \mathrm{dBA}$. Hal ini menunjukkan bahwa aktivitas transportasi yang terjadi di siang hari berpengaruh besar terhadap tingkat kebisingan yang terjadi secara keseluruhan di kawasan eksterior selatan UNP Kampus Air Tawar. Menurut Okokon dkk (2018), kebisingan yang melebihi baku tingkat kebisingan bisa menyebabkan kesehatan mental bagi masyarakat yang terpapar.

Reaksi dan tanggapan penghuni kampus terhadap kebisingan diketahui dengan melakukan penyebaran kuesioner yang terdiri dari beberapa pertanyaan. Penyebaran kuesioner menggunakan metode sampel acak, berjumlah 200 buah kuesioner masing-masing untuk area eksterior dan interior. Penyebaran kuesioner dilakukan secara langsung dengan melakukan interview kepada responden (mahasiswa, karyawan dan dosen UNP). Reaksi reseptor atas kebisingan eksterior yang terjadi di kawasan Selatan UNP Kampus Air Tawar tersebut dapat dilihat pada Gambar 4 sampai dengan Gambar 7.

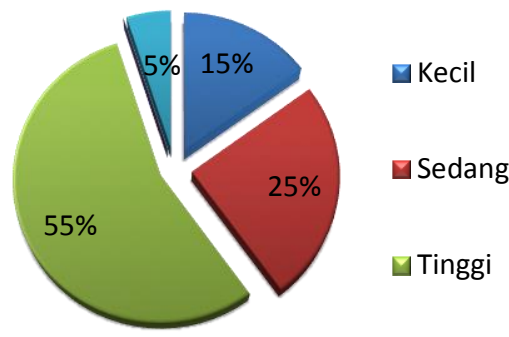

Gambar 4. Tanggapan Responden Berdasarkan Tingkat Kebisingan Eksterior

Dari Gambar 4 di atas terlihat bahwa sebanyak 55\% responden merasa bahwa tingkat kebisingan di kawasan selatan UNP Kampus Air Tawar dalam tingkat tinggi, sementara $25 \%$ merasa tingkat kebisingannya sedang, sedangkan yang merasa tingkat kebisingan kecil hanya $15 \%$ dan sisanya tidak memberikan tanggapan sebanyak $5 \%$. Hasil pengukuran menunjukan tingkat kebisingan di kawasan selatan UNP Kampus Air Tawar berada di atas baku tingkat kebisingan terutama pada daerah yang berada di tepi jalan perlintasan utama maupun jalan-jalan penghubung di kawasan selatan UNP Kampus Air Tawar. Hasil ini sesuai dengan reaksi responden yang merasa bahwa tingat kebisingan di wilayah studi dalam tingkat tinggi. Diagram persentase dari tanggapan responden mengenai tingkat kenyamanan terhadap kebisingan eksterior di wilayah studi disajikan pada Gambar 5.

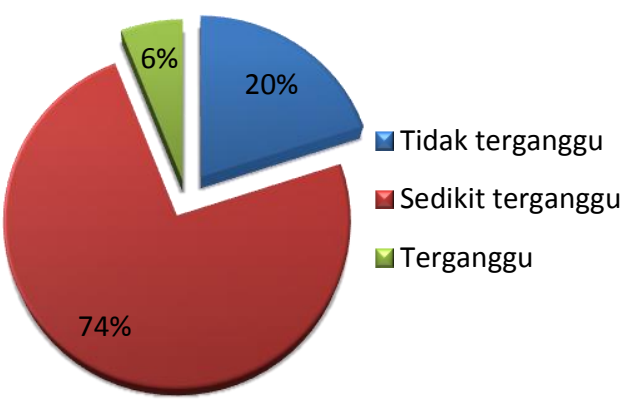

Gambar 5. Tanggapan Responden Berdasarkan Tingkat Kenyamanan Eksterior

Gambar 5 diatas memperlihatkan bahwa sebanyak 20\% responden tidak merasa terganggu dengan kebisingan, 60\% merasa sedikit terganggu dan hanya $12 \%$ yang merasa terganggu dan tidak ada yang merasa sangat terganggu. Hasil evaluasi tingkat kebisingan eksterior di kawasan selatan UNP Kampus Air Tawar menunjukan bahwa seluruh wilayah studi telah melewati baku tingkat kebisingan. Jumlah selisih kebisingan yang melampaui baku tingkat kebisingan terbesar adalah 18,09 dBA yang terdapat di titik S16 Depan GOR UNP. Hal ini disebabkan karena keberadaan reseptor yang berbeda-beda dan sebahagian besar reseptor beraktivitas di dekat gedung perkuliahan dan jauh dari aktivitas transportasi, sehingga bising yang diterima

https://doi.org/10.25077/dampak.15.1.7-15.2018 
tidak terlalu besar, selain itu kebisingan yang diterima dianggap sebagai hal yang biasa terjadi di luar ruangan kampus. kebiasaan dari responden yang berbeda-beda dalam mendengarkan dan menangkap suara inilah yang menimbulkan hasil survei tersebut. Diagram persentase dari tanggapan responden mengenai waktu terjadinya bising eksterior di wilayah studi disajikan pada Gambar 6 berikut.

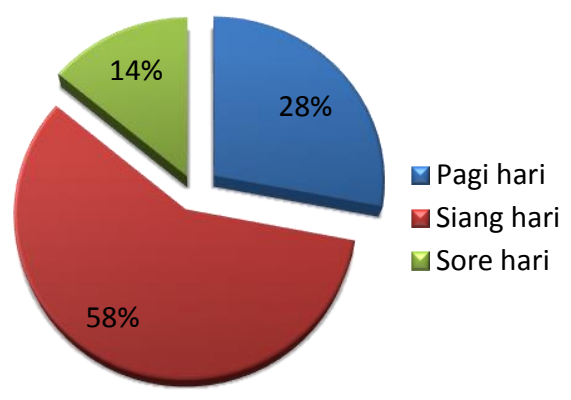

Gambar 6. Tanggapan Responden Berdasarkan Waktu Terjadinya Bising Eksterior

Dari Gambar 6 di atas terlihat bahwa sebanyak 28\% responden merasa kebisingan terbesar dirasakan pada pagi hari, $58 \%$ pada siang hari, $14 \%$ pada sore hari, dan tidak ada yang merasakan bising pada malam hari. Hal tersebut sesuai dengan hasil pengukuran yang menunjukkan tingkat kebisingan tertinggi terjadi pada siang hari $\left(\mathrm{L}_{2}\right)$, dimana pada rentang waktu ini aktivitas transportasi paling banyak terjadi di kawasan selatan UNP Kampus Air Tawar.

Gambar 7 berikut memperlihatkan diagram persentase dari tanggapan responden berdasarkan sumber terjadinya bising eksterior.

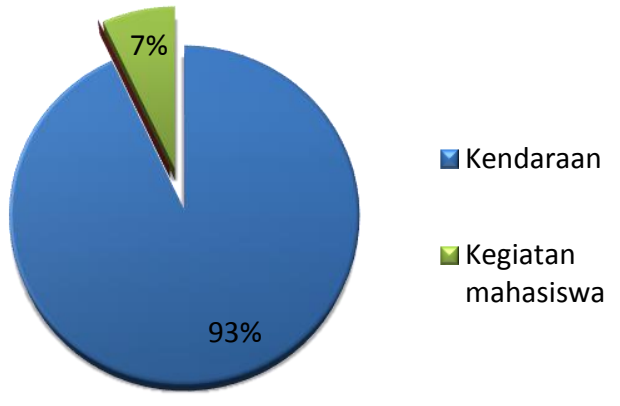

\section{Gambar 7. Tanggapan Responden Berdasarkan Sumber Terjadinya Bising Eksterior}

Gambar 7 di atas memperlihatkan bahwa sebanyak 93\% responden menjawab bahwa kendaraanlah sebagai penyebab utama kebisingan di kawasan selatan UNP Kampus Air Tawar dan hanya 7\% dari responden yang menganggap kegiatan mahasiswa sebagai penyebab utama kebisingan. Hal tersebut sesuai hasil perhitungan tingkat kebisingan yang menyatakan tingkat kebisingan tertinggi berasal dari sektor transportasi (Santika dkk, 2017).

Diagram persentase dari tanggapan responden mengenai perlu atau tidaknya dilakukan pengendalian terhadap kebisingan eksterior dapat dilihat pada Gambar 8 berikut.

https://doi.org/10.25077/dampak.15.1.7-15.2018

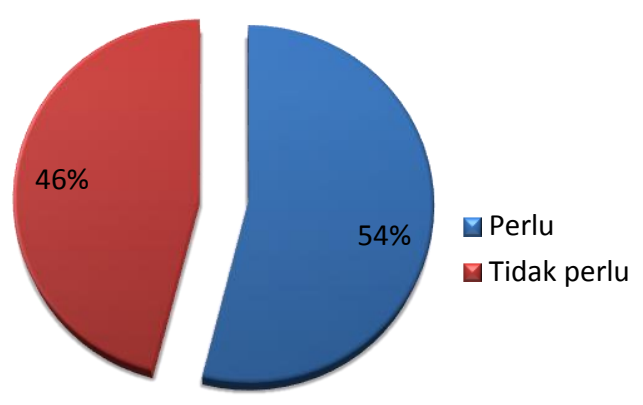

Gambar 8. Tanggapan Responden Berdasarkan Pengendalian Bising Eksterior

Gambar 8 diatas memperlihatkan bahwa hanya 54\% penghuni kampus yang merasa perlu dilakukan pengendalian kebisingan di kawasan selatan UNP Kampus Air Tawar, sedangkan $46 \%$ menyatakan tidak perlu dilakukan pengendalian kebisingan eksterior yang terjadi di kawasan selatan UNP Kampus Air Tawar. Tanggapan para reponden tersebut telah sesuai dengan hasil perhitungan dan efek yang akan dan dapat ditimbulkan oleh tingkat kebisingan yang terjadi di wilayah studi.

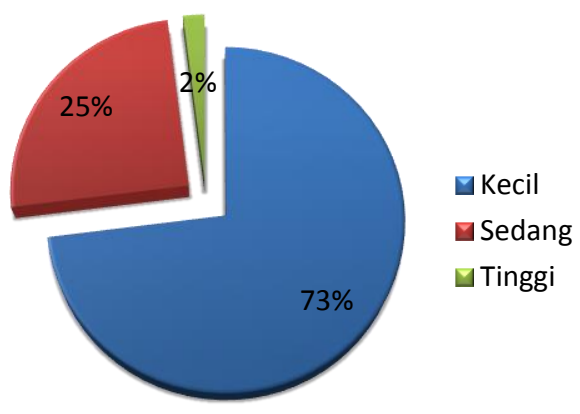

\section{Gambar 9. Tanggapan Responden Berdasarkan Tingkat Kebisingan Interior}

Dari Gambar 9 di atas terlihat bahwa sebanyak $73 \%$ responden merasa bahwa tingkat kebisingan di dalam ruangan dalam tingkat kecil, sementara $25 \%$ merasa tingkat kebisingannya sedang, sedangkan yang merasa tingkat kebisingannya tinggi hanya $2 \%$. Hasil pengukuran menunjukan tingkat kebisingan interior di kawasan selatan UNP Kampus Air Tawar umumnya berada di atas baku tingkat kebisingan baik saat ruangan tersebut dipakai untuk beraktivitas maupun saat kosong, kecuali di titik S6 interior yang nilai $\mathrm{L}_{\mathrm{eq}}$ saat kosong berada di bawah baku mutu. Hal ini diperkirakan terjadi akibat para responden yang umumnya hanya berada di ruangan pada saat dipakai untuk beraktivitas, sehingga tidak menyadari bahwa kebisingan yang dihasilkan saat aktivitas telah melewati baku mutu serta ditambah pengaruh kebisingan eksterior. Diagram persentase dari tanggapan responden mengenai tingkat kenyamanan terhadap kebisingan interior di wilayah studi disajikan pada Gambar 10. 


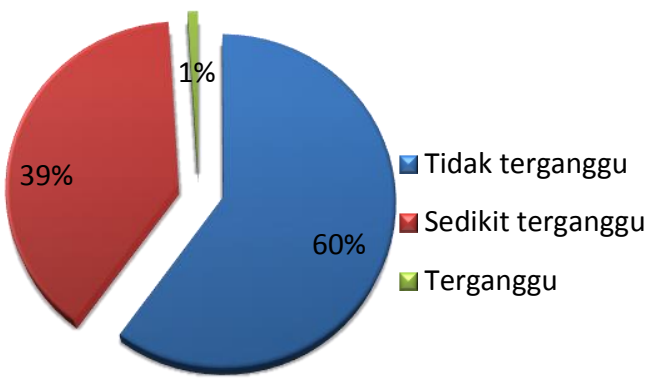

Gambar 10. Tanggapan Responden Berdasarkan Tingkat Kenyamanan Interior

Gambar 10. diatas memperlihatkan bahwa sebanyak $60 \%$ responden tidak merasa terganggu dengan kebisingan, 39\% merasa sedikit terganggu dan hanya $1 \%$ yang merasa terganggu dan tidak ada yang merasa sangat terganggu. Hasil evaluasi tingkat kebisingan interior di kawasan selatan UNP Kampus Air Tawar menunjukan bahwa hampir seluruh wilayah studi telah melewati baku tingkat kebisingan, kecuali pada titik S6 interior saat kosong. Jumlah selisih kebisingan interior yang melampaui baku tingkat kebisingan terbesar adalah 25,99 dBA saat aktivitas dan 6,65 dBA saat kosong. Hal ini disebabkan karena keberadaan reseptor yang berada di dalam ruangan hanya saat aktivitas akademik berlangsung telah menganggap kebisingan yang terjadi pada saat itu merupakan hal yang biasa dan telah menjadi kebiasaan. Hasil survey yang sedikit melenceng ini disebabkan kebiasaan dari responden yang berbeda-beda dalam mendengarkan dan menangkap suara dan kebiasaan reseptor dalam menerima tingkat kebisingan saat beraktivitas di dalam ruangan tanpa mengetahui efek yang akan ditimbulkan oleh kebisingan tersebut.

Diagram persentase dari tanggapan responden mengenai waktu terjadinya bising interior di wilayah studi disajikan pada Gambar 11.

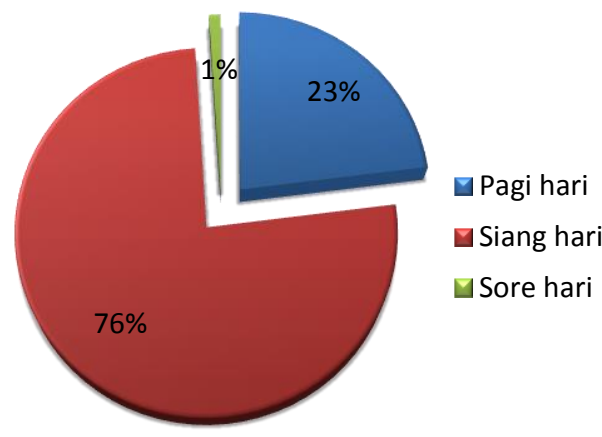

Gambar 11. Tanggapan Responden Berdasarkan Waktu Terjadinya Bising Interior

Dari Gambar 11 di atas terlihat bahwa sebanyak 23\% responden merasa kebisingan interior terbesar dirasakan pada pagi hari, $76 \%$ pada siang hari dan hanya $1 \%$ yang merasakan kebisingan interior pada sore hari serta tidak ada yang merasakan bising pada malam hari. Hal tersebut sesuai dengan hasil pengukuran tingkat kebisingan eksterior yang menunjukkan tingkat kebisingan tertinggi terjadi pada siang hari $\left(\mathrm{L}_{2}\right)$, dimana pada rentang waktu tersebut aktivitas transportasi paling banyak terjadi di kawasan selatan UNP Kampus Air Tawar. Dengan kata lain responden yang berada di dalam ruangan saat aktivitas berlangsung merasakan adanya pengaruh kebisingan eksterior terhadap tingkat kebisingan interior yang mereka rasakan.

Gambar 12 berikut memperlihatkan diagram persentase dari tanggapan responden berdasarkan sumber terjadinya bising interior.

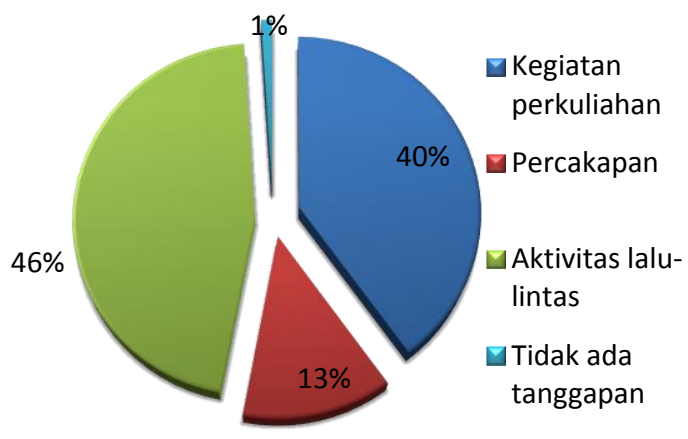

Gambar 12. Tanggapan Responden Berdasarkan Sumber Terjadinya Bising Interior

Gambar 12 di atas memperlihatkan bahwa sebanyak $40 \%$ responden menjawab bahwa aktivitas perkuliahan sebagai penyebab utama kebisingan interior pada kawasan selatan UNP Kampus Air Tawar, 13\% responden menganggap percakapan antar penghuni kampus menjadi penyebab kebisingan interior. Sedangkan $46 \%$ lainnya menganggap aktivitas lalu-lintas sebagai penyumbang utama kebisingan interior yang terjadi serta $1 \%$ sisanya tidak memberikan tanggapan. Hasil survei yang hampir berimbang ini menunjukkan bahwa para reseptor sudah mengetahui aktivitas akademik yang selama ini mereka jalani memiliki tingkat kebisingan yang relatif tinggi bagi mereka. Sedangkan para reseptor lainnya menganggap bahwa aktivitas lalu-lintas memiliki pengaruh terhadap tingkat kebisingan yang terjadi saat mereka melakukan aktivitas di dalam ruangan tersebut.

Diagram persentase dari tanggapan responden mengenai perlu atau tidaknya dilakukan pengendalian terhadap kebisingan interior dapat dilihat pada Gambar 13 berikut.

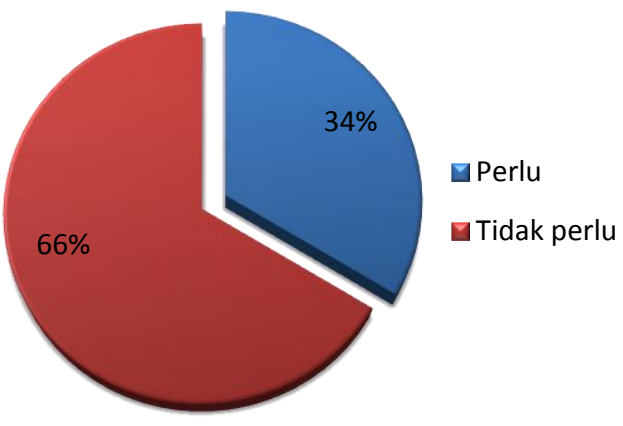

Gambar 13. Tanggapan Responden Berdasarkan Pengendalian Bising Interior 
Gambar 13 di atas memperlihatkan bahwa hanya 34\% penghuni kampus yang merasa perlu dilakukan pengendalian kebisingan interior kawasan selatan UNP Kampus Air Tawar, sedangkan $66 \%$ menyatakan tidak perlu. Bila dibandingkan dengan hasil perhitungan kebisingan interior di wilayah studi, tanggapan tersebut menunjukkan kurangnya kesadaran dan perhatian penghuni kampus terhadap kebisingan sebagai polusi udara serta pengaruh kebisingan terhadap kesehatan. Hal lain yang menjadi penyebab hasil survei ini adalah kebiasaan para penghuni kampus yang menganggap kebisingan interior yang terjadi merupakan hal yang biasa dan tidak perlu dikhawatirkan.

Kontrol kebisingan dilakukan sebagai upaya pengendalian kebisingan ambien untuk mereduksi tingkat kebisingan sampai taraf yang ditentukan oleh baku tingkat kebisingan untuk lingkungan dengan peruntukan tertentu (Laksmono dan Ramita, 2011). Pengendalian tingkat kebisingan yang terjadi di area eksterior kawasan selatan UNP kampus Air Tawar perlu dilakukan untuk meminimalisir perambatan bising (Peterson, 2010) ke area interior sehingga tidak mengganggu proses akademik yang berlangsung. Pengendalian yang akan diterapkan pada area eksterior juga bertujuan untuk mengurangi kebisingan eksisting yang terjadi, sehingga tidak terlalu mempengaruhi para mahasiswa ataupun pihak lain yang aktif berkegiatan di luar ruangan baik dari segi kesehatan maupun kenyamanan mereka.

Umumnya kebisingan yang terjadi di area eksterior bersumber dari aktivitas transportasi (Ogren dkk, 2018) serta kegiatan mahasiswa di luar ruangan baik berupa percakapan non formal maupun praktikum yang bersifat akademis. Beberapa rekomendasi alternatif pengendalian kebisingan yang terjadi di masing-masing titik pengukuran kawasan selatan UNP Kampus Air Tawar tersebut adalah sebagai berikut :

1. Solusi untuk mengurangi tingkat kebisingan di titik S1 bisa dilakukan dengan menambah vegetasi dan kerimbunan vegetasi sebagai peredam alami tingkat kebisingan eksisting. Penanaman tumbuhan jenis Heliconia, Sp yang dikombinasikan dengan pembangunan tembok menerus jenis fiber bening sebagai pembatas jalan dengan ketinggian minimum 3 $\mathrm{m}$ dan lebar minimum $0,5 \mathrm{~m}$ sesuai dengan rujukan tabel 2.4 dan 2.5, mampu mengurangi tingkat kebisingan eksisting sebesar 22 dBA, sehingga kebisingan eksisting dapat direduksi dari nilai 75,57 dBA menjadi 53,57 dBA.

2. penggantian pohon-pohon yang sudah tua atau penambahan vegetasi lainnya seperti Heliconia, Sp diantara pohon-pohon yang sudah tua tersebut dengan jarak yang lebih dekat dan kerimbunan yang lebih efektif untuk meredam kebisingan. Konstruksi tembok jenis fiber bening dengan ketinggian minimum $3 \mathrm{~m}$ dan lebar minimum $0,5 \mathrm{~m}$ sebagai bangunan peredam bunyi di sepanjang pinggiran area Fakultas Teknik juga dapat dipertimbangkan sebagai salah satu alternatif pengendalian kebisingan. Alternatif yang direkomendasikan ini dapat mengurangi kebisingan eksisiting sebesar $22 \mathrm{dBA}$, sehingga dapat mereduksi kebisingan dari 73,25 dBA menjadi 51,25 dBA

3. Pengendalian kebisingan yang dapat dilakukan di area S3 dapat berupa kombinasi antara penanaman Heliconia, Sp dan pembangunan tembok jenis fiber bening dengan ketinggian minimum $3 \mathrm{~m}$ dan lebar minimum $1 \mathrm{~m}$ sebagai pagar pembatas antara bangunan Rektorat sementara dengan jalan. Alternatif ini dapat mengurangi kebisingan dari 73,62 dBA menjadi 51,62 dBA.

4. Alternatif pengendalian kebisingan yang bisa diterapkan pada area S4 dapat berupa kombinasi antara konstruksi tembok jenis menerus fiber bening dengan ketinggian minimum $3 \mathrm{~m}$ dan lebar minimum $0,5 \mathrm{~m}$ sebagai pagar peredam bunyi di salah satu sisi lapangan yang langsung berbatasan dengan jalan serta penanaman Heliconia, Sp yang mampu mereduksi bising dari 70,33 dBA menjadi 48,33 dBA.

5. Alternatif pengendalian yang dapat dilakukan di area S4 lainnya dapat berupa penambahan vegetasi yang cukup rimbun serta memiliki jarak yang cukup rapat untuk meredam kebisingan dari kendaraan yang melewati jalan di area tersebut.

6. Alternatif pengendalian yang dapat dilakukan di titik S5 adalah dengan menambah jumlah vegetasi alami serta kerapatannya dengan tujuan untuk menambah efektifitas meredam kebisingan dari aktivitas lalulintas kendaraan di jalan protokol Prof. DR. HAMKA. Pengendalian tersebut dapat berupa kombinasi penanaman Heliconia, Sp, teh-tehan dan pohon akasia yang mampu mereduksi kebisingan eksisting dari 68,19 dBA menjadi 56,39 dBA.

7. Alternatif pengendalian yang dapat dilakukan di area S6 dapat berupa kombinasi penanaman Heliconia, Sp dan teh-tehan yang mampu mereduksi kebisingan dari 63,24 dBA menjadi 55,54 dBA. Pemasangan peraturan untuk tidak melakukan kegiatan baik berkumpul maupun percakapan di tepi jalan koridor penghubung juga dapat membantu mengurangi kebisingan yang terjadi, sebab sebenarnya di dalam area Fakultas Teknik UNP serta masing-masing jurusannya sudah terdapat taman yang disediakan untuk mengakomodir kegiatan-kegiatan tersebut. Sedangkan untuk mengurangi kebisingan yang berasal dari kegiatan praktikum dapat dilakukan dengan cara menutup jendela laboratorium dan menggunakan ventilasi semi tertutup dengan sistem sirkulasi udara khusus melalui alat pengkondisi udara atau air conditioner.

8. Selain itu pengendalian lainnya juga dapat mengganti lantai koridor dengan dasar yang sedikit lebih licin seperti keramik, teraso, ubin atau lantai dengan dasar air semen yang lebih murah dari segi biaya. Hal ini bertujuan untuk mengurangi bunyi dari gesekan alas kaki para mahasiswa maupun penghuni kampus lainnya dengan dasar lantai ketika melakukan aktivitas jalan kaki di koridor tersebut.

9. Alternatif pengendalian yang dapat dilakukan berupa kombinasi penanaman vegetasi jenis Heliconia, Sp, 
bambu pringgodani dan teh-tehan yang memiliki kemampuan mengurangi kebisingan, sehingga dapat meredam kebisingan di sekeliling area parkir kedua titik tersebut masing-masing dari 68,02 dan 67,35 dBA menjadi 55,42 dBA dan 54,75 dBA

10. Pengendalian kebisingan yang dapat dilakukan di area tersebut dapat berupa penanaman vegetasi jenis Heliconia, Sp dan pohon akasia yang mampu mereduksi di depan dan bagian samping gedung Fakultas FIK sehingga kebisingan eksisting yang mencapai 65,34 dBA dapat dikurangi menjadi 55,94 dBA.

11. Alternatif pengendalian yang dapat dilakukan di titik S9 dapat berupa penambahan vegetasi alami jenis Heliconia, Sp dan pohon akasia yang mampu meredam kebisingan dari jalan, sehingga kebisingan eksisting yang bernilai $65,19 \mathrm{dBA}$ dapat dikurangi menjadi 55,79 dBA.

12. Alternatif pengendalian yang dapat dilakukan di area titik S11 dapat berupa penaambahan vegetasi jenis Heliconia,Sp dan pohon akasia di antara pepohonan yang telah ada. Hal ini bertujuan meningkatkan efektifitas peredaman bising yang bersumber dari kendaraan di jalan. Penambahan ini mampu mereduksi kebisingan sebesar 9,4 dBA, sehingga kebisingan eksisting yang terjadi bisa dikurangi dari $66,33 \mathrm{dBA}$ menjadi 56,93 dBA.

13. Alternatif pengendalian lainnya dapat berupa pengaturan shift kegiatan para mahasiswa dengan tujuan untuk menghindari penumpukan kegiatan yang dapat meningkatkan kebisingan eksisting di sekitar area titik S11.

14. Alternatif pengendalian yang bisa dilakukan di area S13 dapat berupa penggantian pagar semi terbuka dengan konstruksi pagar beton bertulang tidak menerus dengan ketinggian minimum $3 \mathrm{~m}$ dan lebar minimum 1 $\mathrm{m}$ yang dikombinasikan dengan penanaman vegetasi jenis Heliconia, Sp yang mampu mereduksi bising kebisingan eksisting yang terjadi dari 72,18 dBA menjadi 49,18 dBA.

15. Alternatif pengendalian lainnya yang dapat dilakukan di area titik tersebut dapat berupa penanaman vegetasi jenis pohon-pohonan di sepanjang bahu jalan akses penghubung untuk memperkecil pemantulan bunyi kendaraan ke arah dinding bangunan arena kolam renang UNP sehingga mampu meminimalisir akumulasi kebisingan eksisting di area titik S13.

16. Alternatif pengendalian yang dapat dilakukan di kedua area tersebut dapat berupa kombinasi penanaman vegetasi jenis Heliconia, Sp, bambu pringgodani dan teh-tehan yang memiliki kemampuan mengurangi kebisingan di sekeliling area parkir kedua titik tersebut masing-masing dari 66,29 dan 67,79 dBA menjadi 53,69 dBA dan 55,19 dBA.

17. Untuk pengendalian kebisingan area teater terbuka dapat ditambah dengan penggantian vegetasi eksisting dengan vegetasi jenis perdu-perduan yang lebih rapat jaraknya, memiliki kerimbunan daun serta dapat diatur pola tanamnya, contohnya vegetasi jenis teh-tehan yang dapat ditanam membentuk pagar hidup mengelilingi teater terbuka.

18. Alternatif pengendalian yang dapat dilakukan di area tersebut berupa pembangunan pagar menerus dengan bahan jenis fiber bening dengan ketinggian minimum $3 \mathrm{~m}$ dan lebar minimum $0,5 \mathrm{~m}$ yang dikombinasikan dengan tanaman jenis Heliconia, Sp yang mampu mereduksi kebisingan dari 76,09 dBA menjadi 53,09 dBA.

\section{KESIMPULAN}

Hasil analisis tingkat kebisingan eksterior dan interior di Kawasan Selatan Universitas Negeri Padang (UNP) Kampus Air Tawar yakni nilai tingkat kebisingan terendah terjadi saat waktu pengukuran L6 di titik (S8) Depan Lapangan FIK UNP dengan nilai tingkat kebisingan 30,62 dBA, dan nilai tingkat kebisingan tertinggi terjadi saat waktu pengukuran L3 di titik (S16) Depan GOR UNP dengan nilai tingkat kebisingan 80,91 dBA;

Sumber utama penyebab kebisingan area eksterior di Kawasan Selatan Universitas Negeri Padang (UNP) Kampus Air Tawar berasal dari aktivitas transportasi, sedangkan sumber utama kebisingan area interior berasal dari aktivitas akademik di dalam ruangan serta pengaruh bising area eksterior. Berdasarkan KepMenLH No. 48 Th. 1996 Tentang Baku Tingkat Kebisingan disimpulkan bahwa seluruh titik dari total 16 titik pengukuran eksterior memiliki tingkat kebisingan harian melebihi ambang batas baku mutu tingkat kebisingan, sedangkan untuk area interior total dari tujuh titik pengukuran, seluruh titik saat terdapat aktivitas serta enam titik pada saat kosong melebihi baku mutu tingkat kebisingan;

Tanggapan penghuni kampus Kawasan untuk area eksterior yang terjadi didapatkan data bahwa lebih dari sebagian besar responden hanya merasa sedikit terganggu dengan kebisingan yang ada di wilayah studi. Akan tetapi lebih dari sebagian responden merasakan perlunya dilakukan pengendalian terhadap kebisingan eksterior yang terjadi, sementara untuk area interior yang terjadi didapatkan data bahwa lebih dari sebagian besar responden merasakan tidak terganggu sama sekali dengan kebisingan yang ada di wilayah studi serta para responden merasa tidak perlu dilakukan pengendalian terhadap kebisingan interior yang terjadi;

Alternatif pengendalian tingkat kebisingan eksterior di Kawasan Selatan UNP Kampus Air Tawar dapat dilakukan dengan beberapa metode, antara lain :penanaman serta penambahan jumlah vegetasi alami yang berfungsi sebagai bangunan peredam bising (BPB) dengan jenis dan spesifikasi yang sesuai aturan KepMenPU No. 16 th. 2005 Tentang Mitigasi Dampak Kebisingan Akibat Lalu Lintas Jalan; pemasangan tembok jenis fiber bening yang berfungsi sebagai bangunan peredam bising (BPB) dengan jenis dan 
spesifikasi yang sesuai aturan KepMenPU No. 16 th. 2005 Tentang Mitigasi Dampak Kebisingan Akibat Lalu Lintas Jalan di beberapa area titik pengukuran eksterior; Jika memungkinkan maka dapat mengubah sistem sirkulasi udara konvensional yang menggunakan jendela kaca dan ventilasi kayu terbuka dengan sistem sirkulasi udara semi tertutup yang menggunakan alat pengkondisi udara, jendela kaca serta ventilasi jendela yang tertutup. Hal ini bertujuan untuk menghalangi kebisingan dari area eksterior masuk ke dalam ruangan.

\section{REFERENSI}

Alfaris. (2008). Pengaruh Kebisingan Terhadap Tingkat Produktivitas Kerja. Skripsi. Fakultas Kesehatan Masyarakat. Medan: Universitas Sumatera Utara.

Bagian Umum, Hukum/Tatalaksana dan Perlengkapan Universitas Negeri Padang, (2012) (Keterangan informal).

Cunniff, P.F. (1977). Environmental Noise Pollution. Canada: Jhon Willey and Sons.

Keputusan Menteri Lingkungan Hidup No. 48 Tahun 1996 Tentang Baku Tingkat Kebisingan.
Keputusan Menteri Pekerjaan Umum No. 16 Tahun 2005 Tentang Mitigasi Dampak Kebisingan Akibat Lalu Lintas Jalan.

Laksmono, R dan Ramita, N. (2011). Pengaruh Kebisingan Dari Aktifitas Bandara Internasional Juanda Surabaya. Tugas Akhir. Jurusan Teknik Lingkungan. Surabaya: Universitas Pembangunan Nasional "Veteran".

Ogren, M., Molnar, P., \& Barregard, L. (2018). Road Traffic Noise Abatement Scenarios in Gothenburg 2015. Environmental Research, 164, 516-521.

Okokon, E.O., Tuomi, T.Y., Turunen, A.W., Tiittanen, P., Juutilainen, J., \& Lanki, T. (2018). Traffic Noise, Noise Annoyence and Psychotropic Medication Use. Environment International, 119, 287-294.

Peterson, A.P.G. (2010). Handbook of Noise Measurement. Ninth Edition. Massachussets: GenRad.

Santika, B.B., Indrawati, S., Suyatno, \& Yahya, E. (2017). Noise Evaluation of Traffic Flows and Its Effect to Concentration Capability of the Students in One of Private School in Surabaya. Procedia Engineering, 170, 271-279. 